\title{
PERFORMANCE OF ULTRA-LOW RATE OF TRICKLE IRRIGATION
}

\section{Salwa. H. Abdou* ;} Abdel-Ghani. M. El-Gindy ${ }^{*}$
Mahmoud. M. Hegazi";

and Claudia Sorlini ${ }^{*}$

\section{ABSTRACT}

Ultra-low rate technologies are important method of irrigation to water management and save it from lose by runoff in heavy soils or deep percolation in sandy soils.

Ultra low - volume: extremely low water application rates, in the range of 0.1-0.3 l/h per emitter, change the water distribution pattern in soil and other growing beds. In this technology water can be applied to shallow rooted plants with minimum deep percolation.

The aim of these treatments is to investigate performance under three treatments by using low pressure. Results indicated that the use of pulse emitter $(2 \mathrm{~L} / \mathrm{h})$ with $G R$ tube $(2 \mathrm{~L} / \mathrm{h})$ was the best in terms of the Emission Uniformity, which ranged from 90.2 to 93.7 when the operating pressure was $80 \mathrm{kPa}$ and the flow rate was from 0.13 to 0.15 liters / hour.

Key words: Ultra low rate, Minute irrigation, Trickle irrigation, Irrigation performance, Micro irrigation.

\section{INTRODUCTION}

7 rrickle irrigation is very important to keep and management water in arid land and dry areas, because water is lost by runoff in heavy lands with low infiltration rate, and by deep percolation in sandy soils, and in this study we tried to get solve for this problem by using ultra _ low micro irrigation.

This study about new technology allows much smaller volumes of water to be applied through irrigation systems.

Ultra- low irrigation is usually 10 times less than common emitters (i.e. 0.2 1/hr), (Mead, 2002).

\section{Advantages of this system: (Lubars, 2008)}

1. Optimum growth conditions due to the ability to maintain optimum balance of air, water and nutrients in the soil.

\footnotetext{
*Agricultural Engineering Department, Faculty of Agriculture, Ain Shams University

** Agriculture Microbiology Department, Faculty of Agriculture, Milan University
} 
2. Better utilization of available space. Plant density can be increased.

3. Quicker turn around of plant materials reducing growth cycles.

4. Higher yields.

5. Minimize leaching of nutrients that occurs with excess water flow.

6. The ultra- low rate system is much cheaper than the common microirrigtion systems, smaller P.V.C. tubes size reduced horse power requirements.

7. No runoff on heavy soils.

8. No water loss through the root zone on very sandy soils.

9. Water and fertilizer saving up to (40-50) \%.

10. Better quality.

11. Water could be applied efficiently on shallow soils in hilly areas.

\section{MATERIALS AND METHODS}

Experimental site: All experiments were carried out in the Irrigation Laboratory, Agric. Eng. Dep., Faculty of Agriculture, Ain-Shams University. Shoubra El-Khaima, Qalubia Governorate.

Materials: Basic components of system are as follows:

- Poly ethylene hoses with outer diameter "16 mm" and GR line with outer diameter "16 mm" with distance between emitters "32 cm".

- Poly ethylene hoses (spaghetti-tubes) with outer diameter "4 mm".

- Pressure gauges (0-100) $\mathrm{kPa}$, with sensitivity $5 \mathrm{kPa}$.

- Catch cans to collect water.

- Tank for water, with dimensions $40 \times 25 \times 60 \mathrm{~cm}$

- Water pump.

Table (1): Some of characteristics for water pump use.

\begin{tabular}{|c|c|}
\hline Tap water pump & \\
\hline Model: QB 60 & \\
\hline $\mathrm{Q} \max : 35 \mathrm{~L} / \mathrm{min}$ & $\mathrm{H}$ max: $35 \mathrm{~m}$ \\
\hline $0.33 \mathrm{kw} \quad 0.45 \mathrm{HP}$ & $220 \mathrm{~V} \quad 50 \mathrm{~Hz} \quad 2850 \mathrm{r} / \mathrm{min}$ \\
\hline
\end{tabular}


- Online pressure compensating emitter $(2 \mathrm{~L} / \mathrm{h})$.

- Pulse emitter $(2 \mathrm{~L} / \mathrm{h})$.

- Poly ethylene link.

\section{Methods of measurements}

Experimental design: The main objective of this research work is to operate the irrigation system with the lowest allowable pressure and discharge to suit the arid and semi- arid conditions, also to suit the cultivation under green houses.

Three treatments were carried out in the laboratory.

First Treatment: Poly ethylene hoses with outer diameter "16 mm" has been developed in parallel with GR tube $(4 \mathrm{~L} / \mathrm{h})$ with outer diameter 16 mm having twelve emitters horizontally and a link between the P.E. tube and GR tube using (spaghetti-tubes) outer diameter "4 $\mathrm{mm}$ " with length "25 cm". Fig. (1).

Water moves through the online pressure compensating emitter $(2 \mathrm{~L} / \mathrm{h})$, which was the central poly ethylene hoses to GR line.

Pressure was measured by pressure gauges at the pressure compensating emitter and in the end of GR line with length $384 \mathrm{~cm}$.
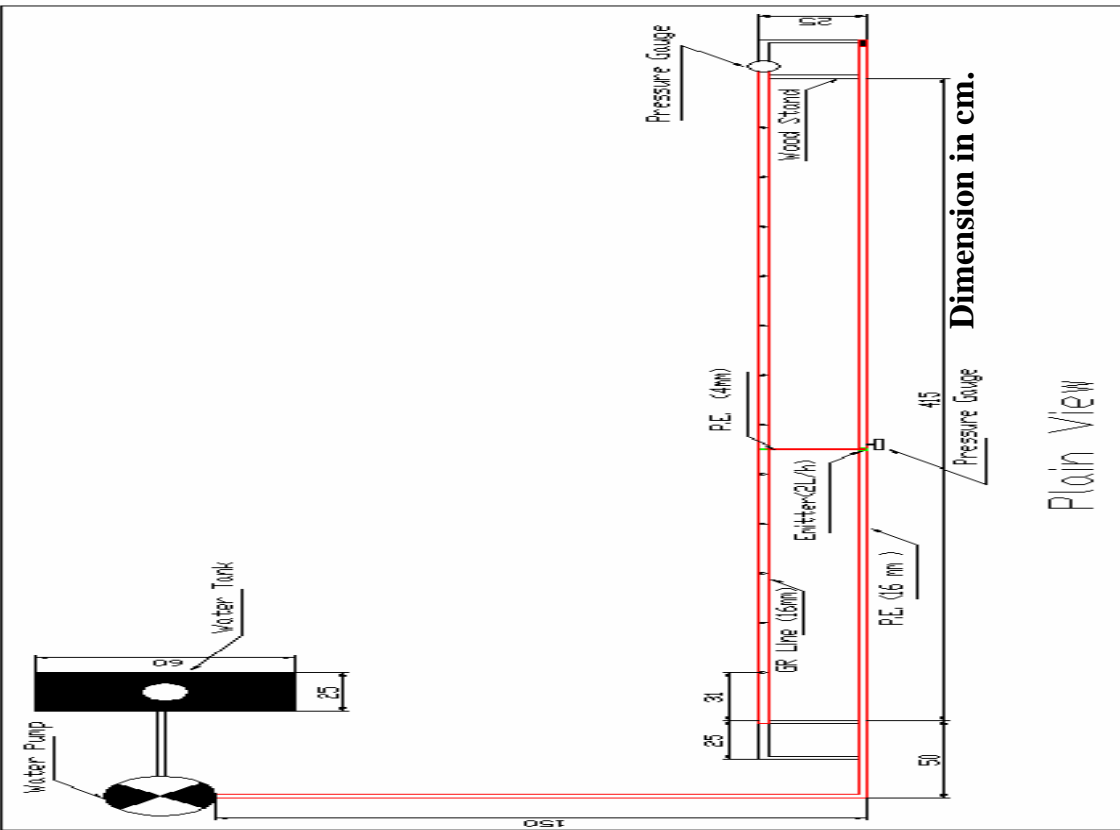

Fig. (1): The prototype of design for first treatment. 
Second Treatment: The same of the first treatment, but GR hoses has been replaced by another GR $2 \mathrm{~L} / \mathrm{h}$.

Third Treatment: The same as the second treatment but the pressure compensating emitter $(2 \mathrm{~L} / \mathrm{h})$ has been replaced by pulse emitter $2 \mathrm{~L} / \mathrm{h}$. Fig. (2).

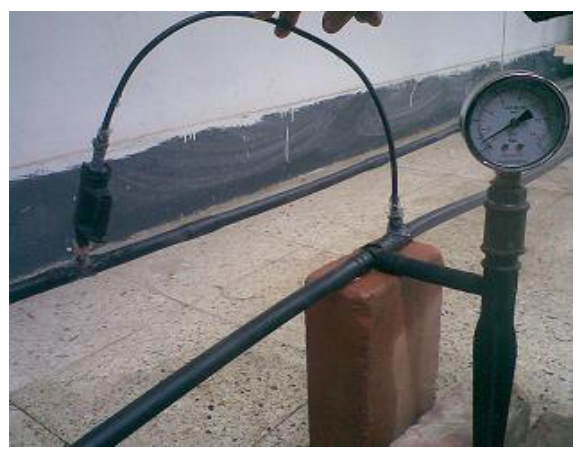

Fig. (2): Third treatment.

\section{Measurements and calculations.}

The efficiency of any localized system depends on the emitters chosen, and is affected by some characteristics as:

Variation in flow rate due to manufacturing coefficient (CV), relation ship between pressure and discharge, design characteristics, allowable range in operating pressure, head losses, sensitivity for clogging, stability of the relationship between pressure and discharge through operating time.

Measuring of discharge (Q): Discharge was measured taken water which collected in catch cans under different pressures from (20 to 200) $\mathrm{kPa}$.

Measuring of pressure (P): pressure was measured by using pressure gauges (100 and 200) kPa, with sensitivity $2 \mathrm{kPa}$.

Measuring of Emission Uniformity (EU): To calculate Emission Uniformity "EU", the following formula was used for 12 emitters and (3.84 m) length, (Al-Amoud, 1997):

Where:

$$
\mathrm{EU}=100 .\left(\mathrm{q}_{\mathrm{n}} / \mathrm{q}_{\mathrm{a}}\right)
$$

$\mathrm{EU}=$ Emission Uniformity, $(\%)$.

qn $=$ Average low quarter of the data emitter, $(\mathrm{L} / \mathrm{h})$.

$\mathrm{qa}=$ Average flow rate of all the data emitter, $(\mathrm{L} / \mathrm{h})$. 
Measuring of manufacturing coefficient "CV": To calculate manufacturing coefficient "CV" for all treatments, the following formula was used for 20 emitters, (Al-Amoud, 1997):

Where:

$C V=$ Manufacturing coefficient. $\quad C V=\frac{s d}{q a}$

$S d=$ Standard deviation, $(\mathrm{L} / \mathrm{h})$.

$q a=$ Average flow rate of all the data emitter, $(\mathrm{L} / \mathrm{h})$.

When:

$$
S d=\sqrt{\frac{q_{1}^{2}+q_{2}^{2}+q_{3}^{2}+\ldots \ldots \ldots . q_{n}^{2}-n q_{a}^{2}}{n-1}}
$$

$n=$ No. of emitters.

Measuring of wetting front: By using two types of soil was used (sandy and loamy soil) and sieved through $2 \mathrm{~mm}$ sive size.

The wetting front was drawn on a transparent paper sheet every hour on surface soil and three operating pressures were used to study the wetting front movement in sandy and loamy soils.

Sensitivity for clogging: Emitter nozzles are designed with diameter ranging from $(0.25 \mathrm{~mm}$ to $2.5 \mathrm{~mm})$ to obtain low flow rate from localized systems, which causes the clogging. (Al-Amoud, 1997).

Sensitivity for clogging was measured by operating the system for (20 hours) and measure emission uniformity at intervals of 2 hours, with a silt of diameter $(0.02-0.002 \mathrm{~mm})$ in water with concentrate (100) $\mathrm{ppm}$ to observe stability in emission uniformity along operating time.

Following formula was used to calculate clogging ratio:

Where:

$$
\left(\frac{q_{1}-q_{2}}{q_{1}}\right) \times 100
$$

$\mathrm{q}_{1}=$ Average flow rate at start up operating, (L/h).

$\mathrm{q}_{2}=$ Average flow rate at the end operating, $(\mathrm{L} / \mathrm{h})$.

\section{RESULTS AND DISCUSSION}

First treatment: The relationship between pressure $(\mathrm{kPa})$ and flow rate $(\mathrm{L} / \mathrm{h})$ at $\left(25-26^{\circ} \mathrm{C}\right)$ is shown in Fig. (3) Showing an increase in flow rate by increasing pressure, where at $60 \mathrm{kPa}$ flow rate was $0.12 \mathrm{~L} / \mathrm{h}$, and when pressure increased to $100 \mathrm{kPa}$, flow rate increased to $0.18 \mathrm{~L} / \mathrm{h}$. Figure (4) describes emission uniformity which was $(53.7-82.8) \%$. The lowest 
pressure with acceptable emission uniformity (70\%) was $76 \mathrm{kPa}$ and flow rate $0.15 \mathrm{~L} / \mathrm{h}$, the treatment was not up to the level of acceptable C.V.

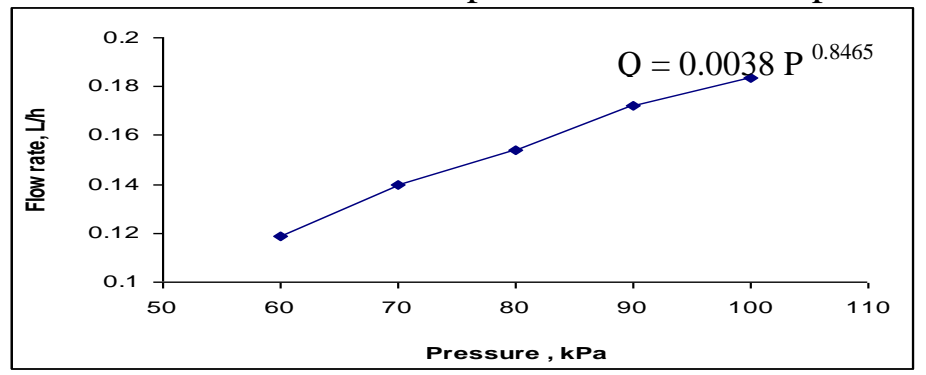

Fig. (3): Relationship between pressure and flow rate at GR $(4 \mathrm{~L} / \mathrm{h})$, pressure compensating emitter $(2 \mathrm{~L} / \mathrm{h})$.

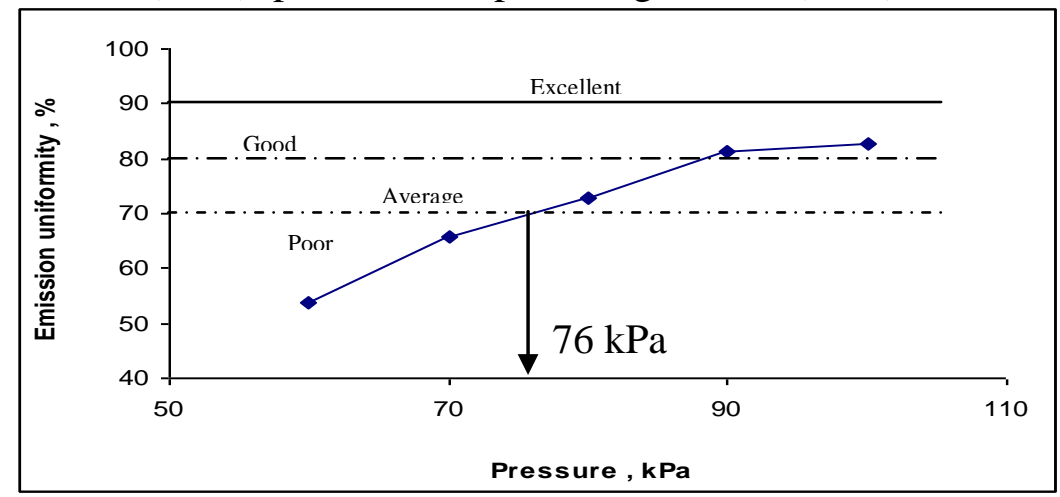

Fig. (4): Emission uniformity for first treatment.

Second treatment: The relationship between pressure $(\mathrm{kPa})$ and flow rate at $\left(25-26^{\circ} \mathrm{C}\right)$ is shown in Fig.(5) Showing an increase in flow rate by increasing in pressure, where at $40 \mathrm{kPa}$ the flow rate was $0.09 \mathrm{~L} / \mathrm{h}$, and when pressure increased to $100 \mathrm{kPa}$ flow rate increased to $0.17 \mathrm{~L} / \mathrm{h}$. Figure (6) described emission uniformity which was $(73.5-90.9) \%$ and the lowest pressure with acceptable C.V. (0.1) and emission uniformity (88.28\%) acceptable was $90 \mathrm{kPa}$ and flow rate was $0.17 \mathrm{~L} / \mathrm{h}$.

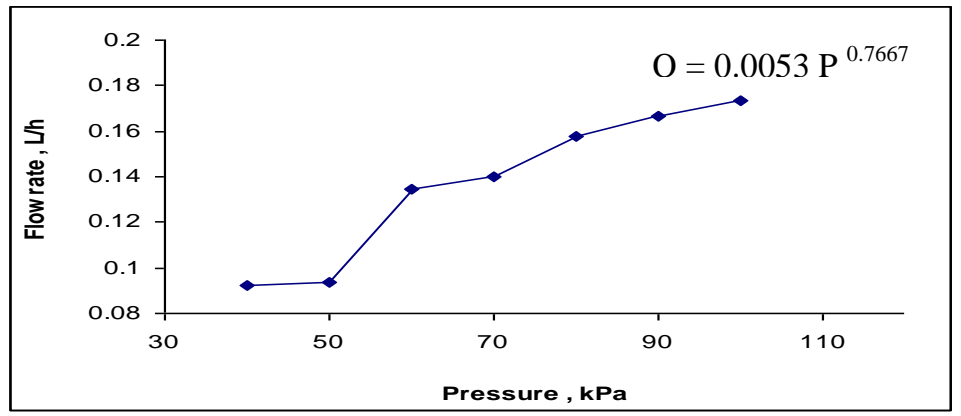

Fig. (5): Relationship between pressure and flow rate at GR (2L/h), pressure compensating emitter $(2 \mathrm{~L} / \mathrm{h})$. 


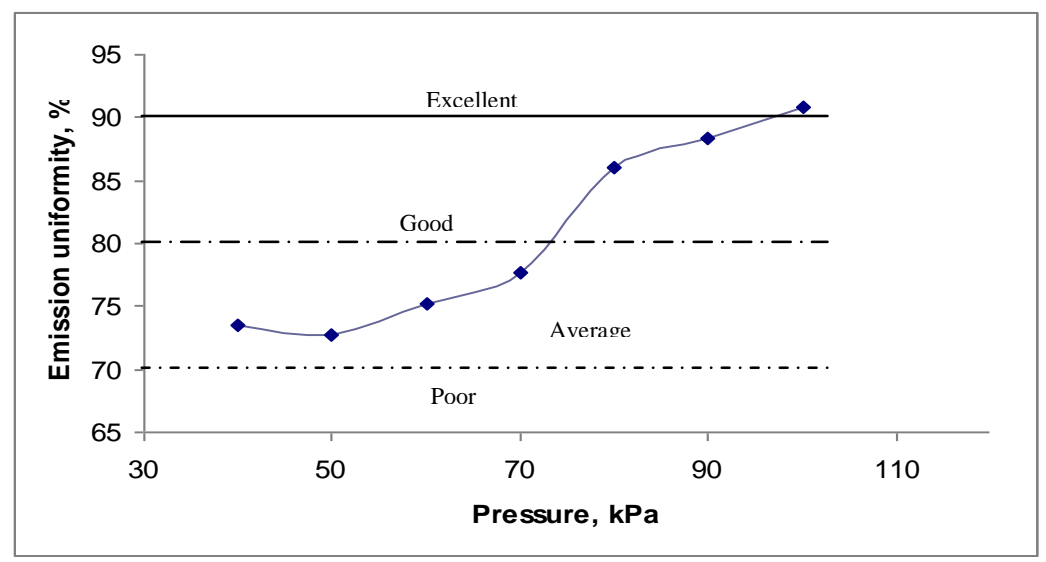

Fig. (6): Emission uniformity for second treatment.

Third treatment: Fig. (7) describes increase in flow rate by increasing in pressure at $\left(25-26^{\circ} \mathrm{C}\right)$, when at pressure $70 \mathrm{kPa}$, flow rate was $0.013 \mathrm{~L} / \mathrm{h}$, and when pressure increased to $100 \mathrm{kPa}$ flow rate increased to $0.22 \mathrm{~L} / \mathrm{h}$ the lack of flow rate at $70 \mathrm{kPa}$ was due to the pulse emitter does not work at this pressure. Figure (8) describe emission uniformity which was (1591) $\%$ and the lowest pressure with acceptable C.V. and emission uniformity $(88.7 \%$ ) was $80 \mathrm{kPa}$ and flow rate was $0.15 \mathrm{~L} / \mathrm{h}$.

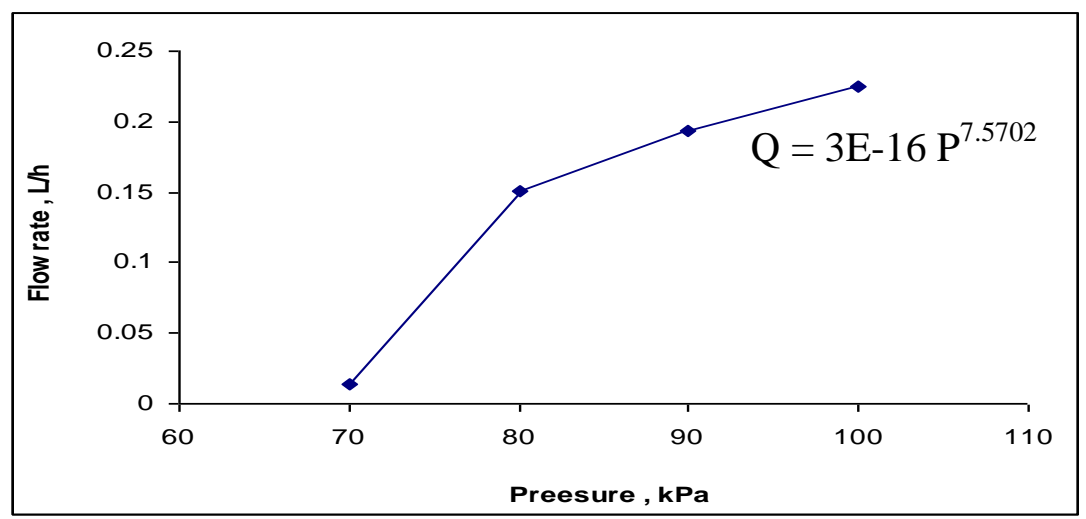

Fig. (7): Relationship between pressure and flow rate at GR (2L/h), pulse emitter $(2 \mathrm{~L} / \mathrm{h})$. 


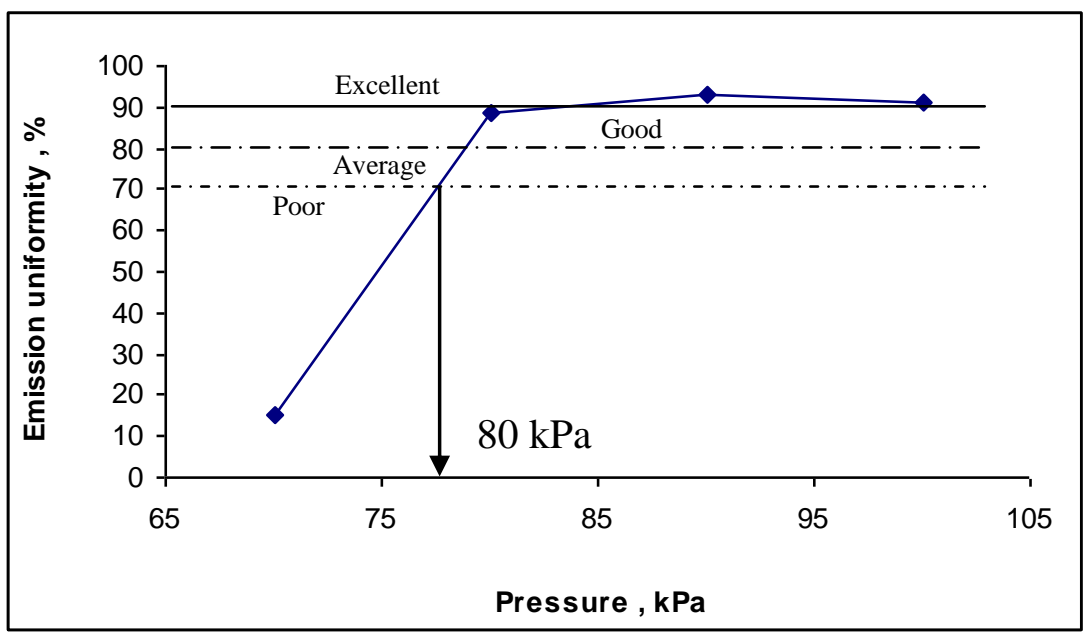

Fig. (8): Emission uniformity for third treatment.

\section{Manufacturing coefficient (CV):}

Figure (9) shows manufacturing coefficient "CV" for all treatments, which ranged between (0.132-0.36) for first treatment, (0.07-0.22) for second treatment and (0.07-0.95) for third treatment. But at $70 \mathrm{kPa}$ for third treatment $(\mathrm{CV})$ was not acceptable because pulse emitter does not work at this pressure.

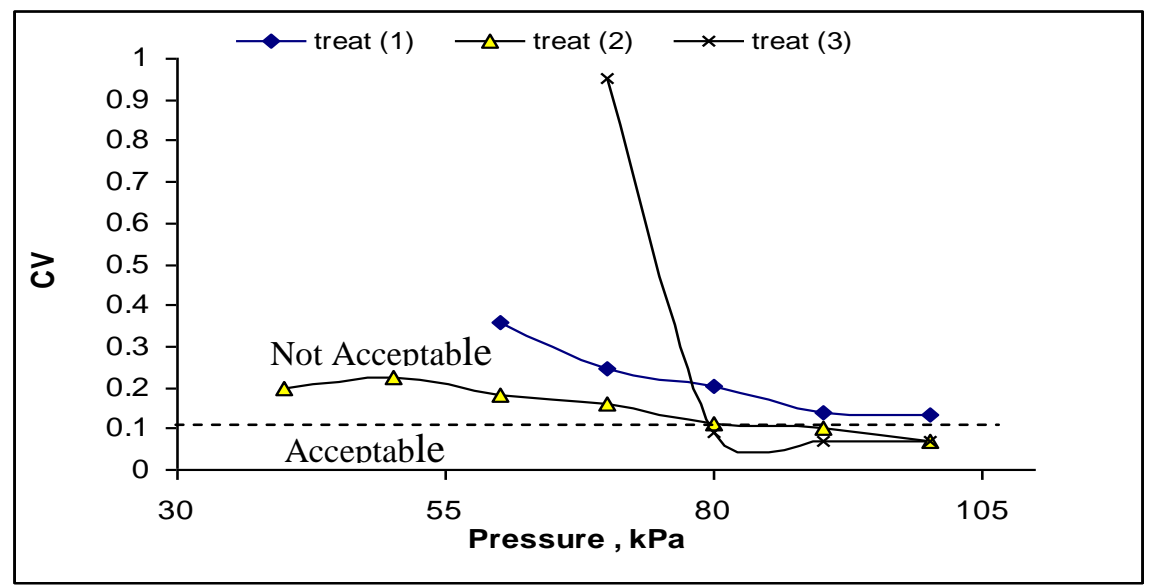

Fig. (9): Manufacturing coefficient "CV" for all treatments. 
Sensitive for clogging: Treatments were carried out by using water with silt contamination (0.02 -0.002 $\mathrm{mm}$ in diameter) with concentrate (100) $\mathrm{ppm}$. Discharge was measured every two hours for twenty hours. It is clear from the fig. (10) that the third treatment was the best because it has steady flow rate over time which was between $(0.13-0.15) \mathrm{L} / \mathrm{h}$ and the highest emission uniformity which was at range (90.2-93.7\%), this is due to the pulse emitter is resistant to clogging.

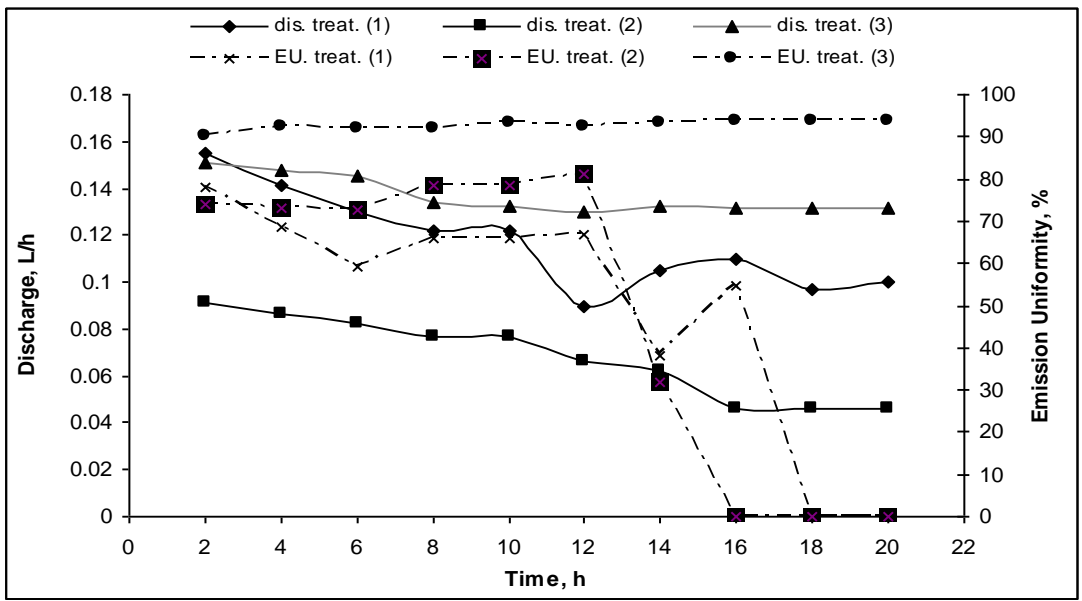

Fig. (10): Sensitive for clogging by the time for all treatments.

In the first treatment, the flow rate was ranged from 0.09 to $0.04 \mathrm{~L} / \mathrm{h}$ and there was a decrease in emission uniformity curve (77.9 to $0 \%$ ) due to clogging which occurs with emitters over time, after twelve hours and flow rate $(0.09) \mathrm{L} / \mathrm{h}$, there was a decrease in the flow rate because of the accumulation of silt particles in the emitters. In the second treatment the flow rate was ranged from 0.15 to $0.1 \mathrm{~L} / \mathrm{h}$ and there was a decrease in emission uniformity curve (73.9 to $0 \%$ ) duo to clogging which accident with emitters over time Thus, there was a decrease in the flow rate at the time number (12) at flow rate (0.06) L/h because of the accumulation of silt particles in the emitters. In the third treatment the flow rate was ranged from 0.15 to $0.13 \mathrm{~L} / \mathrm{h}$ and there was an increase in emission uniformity curve (90.26 to $93.67 \%$ ) due to resistance for clogging at pulse emitter.

Clogging ratio was $35.41,49.68$ and $12.61 \%$ for first, second and third treatments respectively. 
Wetting pattern front: Wetting pattern front was drawn every hour for both clay and sandy soil at (0.018 to 0.4$) \mathrm{L} / \mathrm{h}$. Figure (11) illustrate that wetting pattern front for sand and clay soils increased in both directions by increasing flow rate (horizontal and vertical).With comparison between sand and clay the figure showed that the vertical wetting pattern front in sandy soil increase more than vertical in clay with $36.07 \%$, but the horizontal wetting pattern front in clay soil increase more than horizontal in sand with $13.08 \%$.

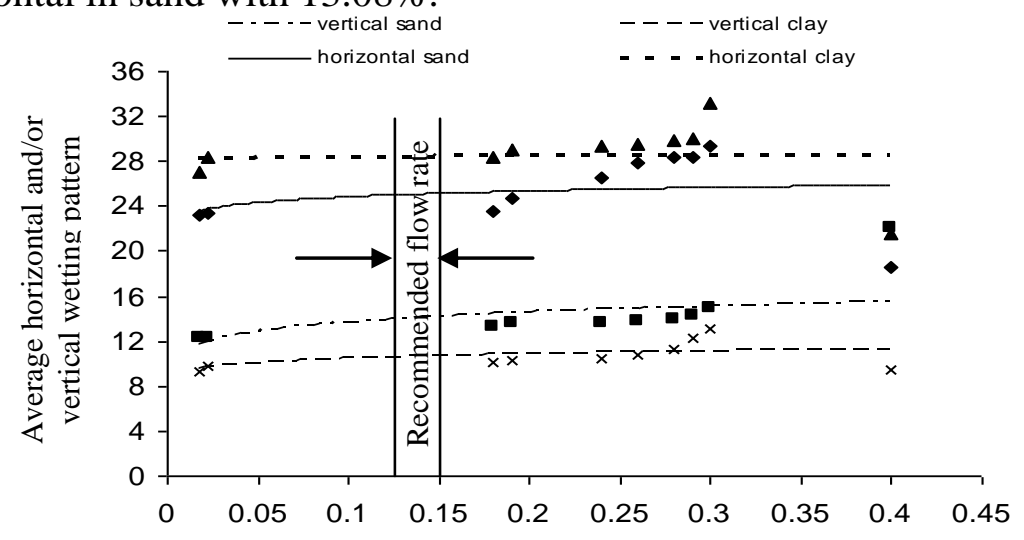

Flow rate, $\mathrm{L} / \mathrm{h}$

Fig. (11): Wetting pattern tront tor sand and clay soils.

By comparing traditional trickle flow $8 \mathrm{~L} / \mathrm{h}$ and ultra-low rate system 0.4 $\mathrm{L} / \mathrm{h}$ for the same water quantity 2.4 Liter, wetting pattern front for sand and clay soils at traditional trickle flow were faster than wetting pattern front at ultra-low rate system, which led to a significant loss in the amount of water by deep percolation in a short time, as Figs. (12-13) shown.
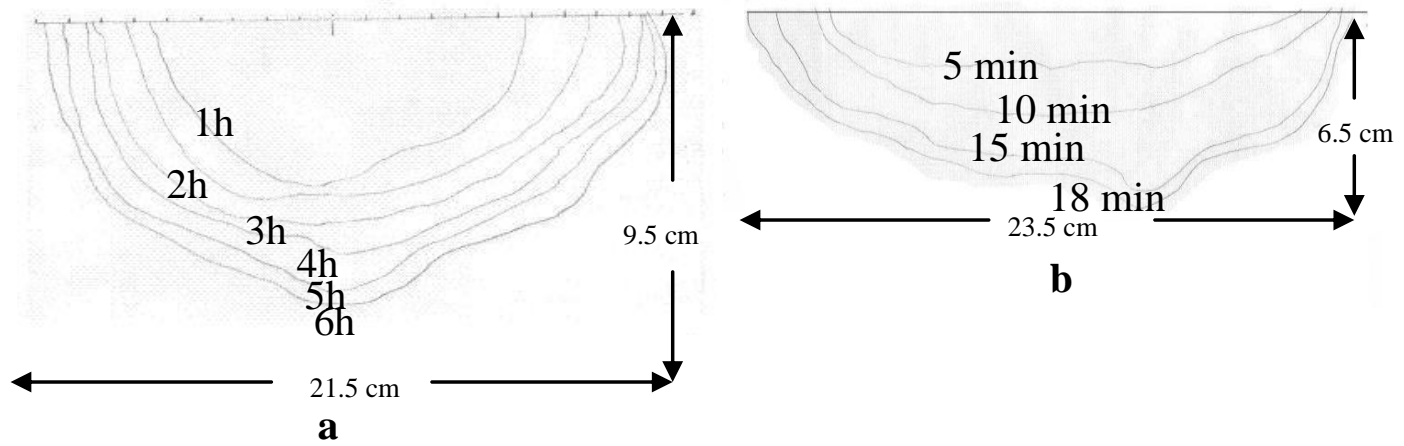

b

Fig. (12): Wetting pattern front in clay soil for: a: Ultra-low rate system $(0.4 \mathrm{~L} / \mathrm{h})$ after 6 hours, b: traditional trickle flow $(8 \mathrm{~L} / \mathrm{h})$ after 18 minute. 


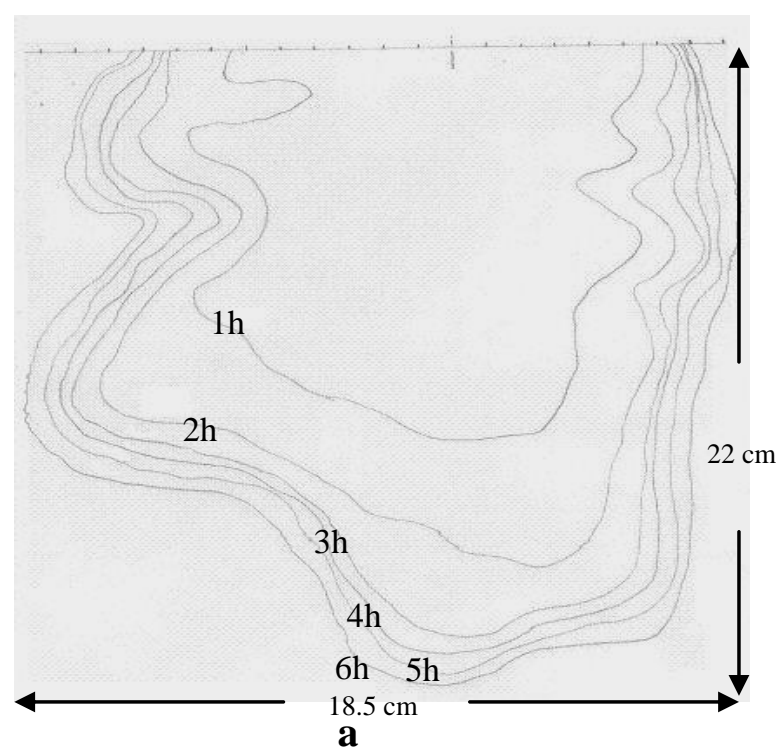

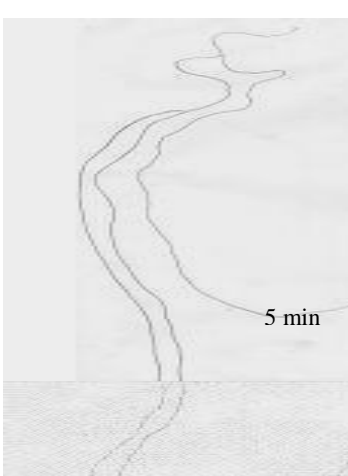

$10 \mathrm{~min}$

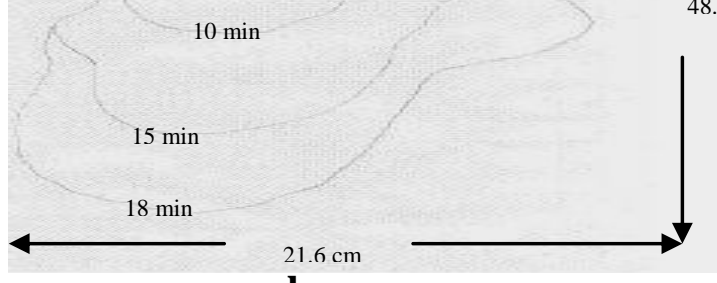

b

Fig. (13): Wetting pattern front in sand soil for: a: Ultra-low rate system $(0.4 \mathrm{~L} / \mathrm{h})$ after 6 hours, b: traditional trickle flow $(8 \mathrm{~L} / \mathrm{h})$ after 18 minute.

In traditional trickle flow the vertical wetting pattern fronts in sandy soil increase more than vertical in clay with $646.15 \%$, but the horizontal wetting pattern front in clay soil increase more than horizontal in sand with $8.8 \%$.

\section{Cost data}

\section{A: Structural costs}

By comparing between Ultra-low rate of trickle irrigation system and traditional system, a calculating total structural costs per five fed was as shown in table (2), which was 23872.7 L.E. for Traditional drip irrigation while was 31852.15 L.E. for Ultra-low rate system.

\section{B: Energy requirements}

Total area ( 5 fed) has been divided into four quarters in both designs and each quarter has been run separately. The imposition of the crop grown is cucumbers, which grows in $(40 \mathrm{~cm})$ and total water requirement 10 $\mathrm{m}^{3} /$ fed/day. (Hassan, 1991). Table (3) shows the operating requirements of the two systems. 
IRRIGATION AND DRAINAGE

Table (2): Cost analysis for Traditional trickle irrigation and Ultra-low rate system, these prices are for the year 2010. Traditional drip irrigation.

\section{Ultra-low rate system.}

\begin{tabular}{|c|c|c|c|c|c|c|c|c|c|}
\hline Type & Unit & Quantity & $\begin{array}{l}\text { Price, } \\
\text { L.E. }\end{array}$ & Total & Type & Unit & Quantity & Price, L.E. & Total \\
\hline \multicolumn{5}{|l|}{ 1-P.V.C. pipe } & \multicolumn{5}{|l|}{ 1-P.V.C. pipe } \\
\hline $110 \mathrm{~mm} / 4 \mathrm{bar}$ & $\mathrm{m}$ & 170 & 8.5 L.E. & 1445 L.E. & $32 \mathrm{~mm} / 4$ bar & $\mathrm{m}$ & 160 & 2 L.E. & 320 L.E. \\
\hline $90 \mathrm{~mm} / 4 \mathrm{bar}$ & $\mathrm{m}$ & 160 & 5.7 L.E. & 912 L.E. & $40 \mathrm{~mm} / 4 \mathrm{bar}$ & $\mathrm{m}$ & 170 & 2.45 L.E. & 416.5 L.E. \\
\hline P.V.C. fitting & \multicolumn{3}{|c|}{$10 \%$ from P.V.C. total } & 235.7 L.E. & P.V.C. fitting & \multicolumn{3}{|c|}{$10 \%$ from P.V.C. total } & 73.65 L.E. \\
\hline \multicolumn{5}{|l|}{ 2- valves } & \multicolumn{5}{|l|}{ 2- valves } \\
\hline Butterfly valve & number & $\begin{array}{l}1 \times 4 \text { inch } \\
4 \times 3 \text { inch }\end{array}$ & $\begin{array}{l}340 \text { L.E. } \\
275 \text { L.E. }\end{array}$ & $\begin{array}{l}340 \text { L.E. } \\
1100 \text { L.E. }\end{array}$ & Ball valve & number & $5 \times 1$ inch & 25 L.E. & 125 L.E. \\
\hline 3- P.E. pipe & & & & & \multicolumn{5}{|l|}{ 3- P.E. pipe } \\
\hline GR $18 \mathrm{~mm}$ & $\mathrm{~m}$ & $\begin{array}{c}20800 \\
\text { (59 laps) }\end{array}$ & $\begin{array}{c}280 \\
\text { L.E./ lap } \\
\end{array}$ & 16520 L.E. & $16 \mathrm{~mm}$ & $\mathrm{~m}$ & 20800 (52 laps) & 260 L.E./lap & 13520 L.E. \\
\hline \multirow[t]{4}{*}{ P.E. fitting } & \multicolumn{4}{|c|}{1320 L.E. } & GR $16 \mathrm{~mm}$ & $\mathrm{~m}$ & 20800 (52 laps) & 280 L.E./lap & 14560 L.E. \\
\hline & & & & & $4 \mathrm{~mm}$ & $\mathrm{~m}$ & 1360 (3 laps) & 160 L.E./lap & 480 L.E. \\
\hline & & & & & P.E. fitting & \multicolumn{4}{|c|}{1074 E.L } \\
\hline & & & & & $\begin{array}{c}\text { 4- Tricklers } \\
\text { Pulse emitter } \\
(2 \mathrm{~L} / \mathrm{h})\end{array}$ & number & 5416 & 0.20 L.E. & 1083 L.E. \\
\hline \multicolumn{2}{|c|}{ 4-Pump (1.125 kW) $1.5 \mathrm{Hp}$} & & 2000 L.E. & & $\begin{array}{c}\text { 5-Pump } \\
(0.063 \mathrm{~kW}) \\
0.084 \mathrm{Hp} \\
\end{array}$ & \multicolumn{4}{|c|}{200 L.E. } \\
\hline \multicolumn{2}{|c|}{ TOTAL } & \multicolumn{3}{|c|}{ 23872.7 L.E. } & TOTAL & \multicolumn{4}{|c|}{ 31852.15 L.E. } \\
\hline
\end{tabular}

Misr J. Ag. Eng., April 2010 
Table (3): The operating requirements for the two systems (5 fed).

Ultra low rate system

\begin{tabular}{|c|c|c|c|}
\hline Data & Traditional system & $\begin{array}{c}\text { Pulse emitter } 2 \\
\text { L/h. }\end{array}$ & $\begin{array}{l}\text { pressure } \\
\text { compensating } \\
\text { emitter } 2 \mathrm{~L} / \mathrm{h} \text {. }\end{array}$ \\
\hline Cultivated plants & $1 \times 0.4 \mathrm{~m}$ & $1 \times 0.4 \mathrm{~m}$ & $1 \times 0.4 \mathrm{~m}$ \\
\hline $\begin{array}{l}\text { Water requirement per a } \\
\text { quarter of the area }\end{array}$ & 12500 liter / day & 12500 liter/day & 12500 liter / day \\
\hline $\begin{array}{l}\text { Available for a quarter of } \\
\text { the space }\end{array}$ & 32500 liter / h & 2275 liter / h & 2762.5 liter $/ \mathrm{h}$ \\
\hline $\begin{array}{l}\text { Lowering time to irrigate } \\
\text { a quarter of the space }\end{array}$ & $\begin{array}{l}12500 / 32500=0.4 \mathrm{~h} / \\
\text { day }\end{array}$ & $\begin{array}{l}12500 / 2275=5 \mathrm{~h} \\
/ \text { day }\end{array}$ & $\begin{array}{l}12500 / 2762.5=4.5 \\
\mathrm{~h} / \text { day }\end{array}$ \\
\hline $\begin{array}{l}\text { Lowering time for each } \\
\text { segment }\end{array}$ & 2 hours / day & 20 hours / day & 18 hours / day \\
\hline Total head & $12.26 \mathrm{~m}$ & $10.06 \mathrm{~m}$ & 11.06 \\
\hline Power required & $1.125 \mathrm{~kW}$ & $0.063 \mathrm{~kW}$ & $0.069 \mathrm{~kW}$ \\
\hline
\end{tabular}

Supposing that the source of energy electricity and the price per $\mathrm{kW}$ per hour 0.11 L.E. $/ \mathrm{h}$, thus the cost of energy during the day in Ultra low rate system (pulse emitter $2 \mathrm{~L} / \mathrm{h}$ ) was 0.138 L.E. /day, Ultra low rate system (pressure compensating emitter $2 \mathrm{~L} / \mathrm{h}$ ) was 0.136 L.E. /day and in Traditional system was 0.25 L.E. /day. Thus, we note that Ultra low rate system (pressure compensating emitter $2 \mathrm{~L} / \mathrm{h}$ ) was the lowest cost.

\section{SUMMARY AND CONCLUSION}

Three treatments were carried out in this study, and the aim of this study to test the performance.

For the first treatment, there was an increase in the discharge by increasing in pressure. At a pressure of $60 \mathrm{kPa}$ the discharge was $0.12 \mathrm{~L} /$ $\mathrm{h}$ and when the pressure increased to $100 \mathrm{kPa}$, discharge reached to $0.18 \mathrm{~L}$ / h. emission uniformity was $(53.7-82.8) \%$ and the lowest pressure at which the emission uniformity acceptable was $76 \mathrm{kPa}$ and flow rate was $0.15 \mathrm{~L} / \mathrm{h}$, and the treatment was not within the limits of acceptable C.V.

For the second treatment, when pressure of $40 \mathrm{kPa}$ the discharge was $0.09 \mathrm{~L} / \mathrm{h}$ and when the pressure increased to $100 \mathrm{kPa}$, the flow rate increased to $0.17 \mathrm{~L} / \mathrm{h}$. emission uniformity was $(73.5-90.9) \%$ and the 
lowest pressure at which C.V. acceptable and emission uniformity $(88.28 \%)$ was acceptable at $90 \mathrm{kPa}$ and flow rate was $0.17 \mathrm{~L} / \mathrm{h}$.

For the third treatment, when pressure of $70 \mathrm{kPa}$ the discharge was $0.013 \mathrm{~L} / \mathrm{h}$ and when the pressure is increased to $100 \mathrm{kPa}$ discharge reached to $0.22 \mathrm{~L} / \mathrm{h}$, and a severe shortage in the discharge at $70 \mathrm{kPa}$ due to pulse emitter that does not work but on top of $70 \mathrm{kPa}$, and Emission Uniformity which was $(15-91) \%$ and the lowest pressure at which C.V. was acceptable and emission uniformity $(88.7 \%)$ acceptable was $80 \mathrm{kPa}$ and flow rate was $0.15 \mathrm{~L} / \mathrm{h}$.

Manufacturing coefficient (CV): The coefficient of variation of manufacturing for all treatments was as follows: The first treatment was in the range of (0.132-0.36) and in the second treatment was the range of (0.07-0.22) and the third treatment ranged from (0.07-0.95).

Sensitivity for clogging: Treatments were conducted using water with silt (0.02 -0.002) $\mathrm{mm}$ with concentration (100 ppm), was measured every two hours for 20 hours. The third treatment was the best because it has steady flow rate over time which was between $(0.13-0.15) \mathrm{L} / \mathrm{h}$ and the highest emission uniformity was at range $(90.2-93.7 \%)$, this is due to the pulse emitter resistance to clogging. In the first treatment flow rate was $(0.09-$ $0.04) \mathrm{L} / \mathrm{h}$ and there was a decrease in emission uniformity curve (77.9 $0 \%$ ) duo to clogging which occurs with emitters over time. In second treatment flow rate was $(0.15-0.1) \mathrm{L} / \mathrm{h}$ and there was a decrease in emission uniformity curve $(73.9-0 \%)$ duo to clogging which occurs with emitters over time. Clogging ratio was 35.41, 49.68 and $12.61 \%$ for first, second and third treatments respectively.

Wetting front: Vertical wetting pattern front in sandy soil increased more than vertical in clay with $36.07 \%$, but the horizontal wetting pattern front in clay soil increased more than horizontal in sand with $13.08 \%$.

Costs analysis: Costs were calculated for five fed. under traditional trickle flow system and ultra-low rate system under the same operating conditions and total costs for conventional irrigation 23872.7 EL and ultra-low rate 31832.15 EL.

Energy requirements: Total area ( 5 fed) has been divided into four quarters in both designs and each quarter has been separately. The cost of energy during the day in Ultra low rate system (pulse emitter $2 \mathrm{~L} / \mathrm{h}$ ) was 
0.138 L.E/day, Ultra low rate system (pressure compensating emitter 2 $\mathrm{L} / \mathrm{h}$ ) was $0.136 \mathrm{~L} . \mathrm{E} /$ day and in Traditional system was $0.25 \mathrm{~L} . \mathrm{E} /$ day.

Recommendation: Finally the third treatment was the best in terms of the Emission Uniformity, which ranged from 90.2 to $93.7 \%$ when the operating pressure was $80 \mathrm{kPa}$ and the flow rate from 0.13 to 0.15 liters / hour, where the pulse emitter have resistance for clogging which helps to stabilize the discharge over operation.

\section{REFERNCE}

Al-Amoud, A. I., 1997. Trickle irrigation system, King Saud University: 137-143.

Hassan, A. A., 1991. The production of vegetable crops, VOL.1, Cairo University: 219-235.

Lubars, P. (2008) http://www.scribd.com/doc/8145273/p13

Mead, R. (2002) http://www.americanfarm.com/signe\%2010-01.htm1

\section{الملخص العربى}

أداء الري بالتنقيط الفائق القلة
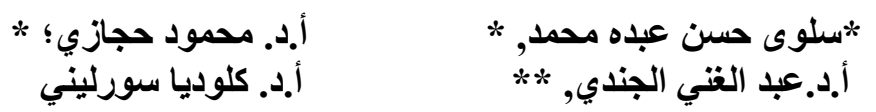

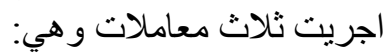

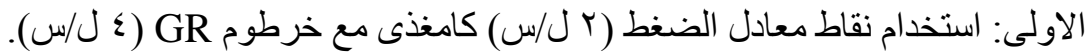

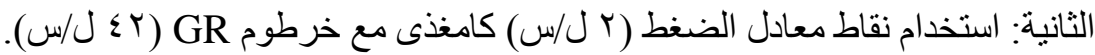

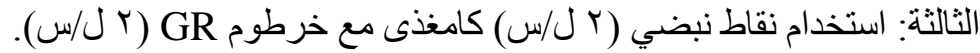
وتم إيجاد معدل الأداء لكل معاملة, وكانت أهم النتائن النائج كالأتي:

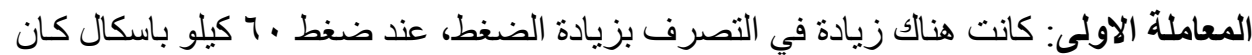

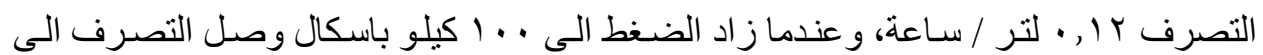

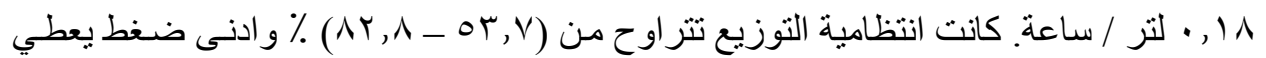

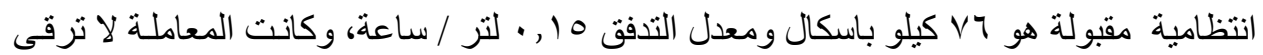

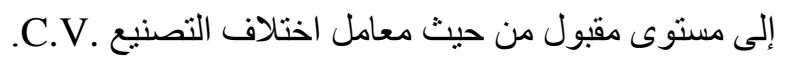

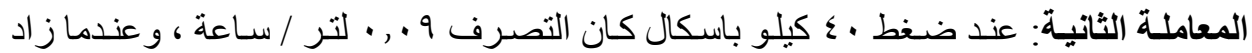

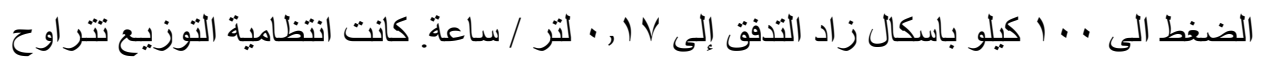

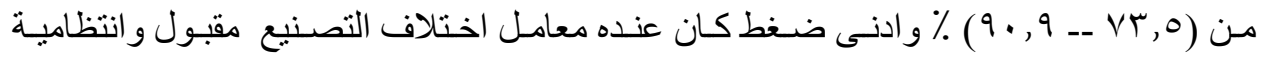

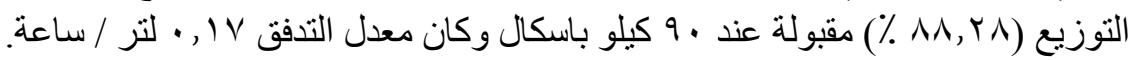

$$
\begin{aligned}
& \text { * قسم الهندسة الزر اعية ـ كلية الزر اعة ـ جامعة عين شمس } \\
& \text { ** قسم الميكروبيولوجيا - كلية الزر اعة - جامعة ميلانو }
\end{aligned}
$$


المعاملة الثالثة: عند ضغط • V كيلو باسكال كان التصرف با ب . , • لتر / سـاعة و عندما زداد

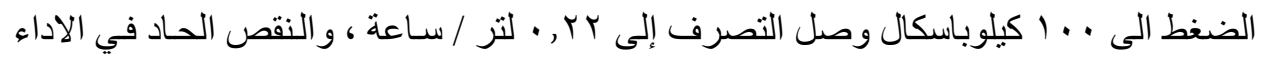

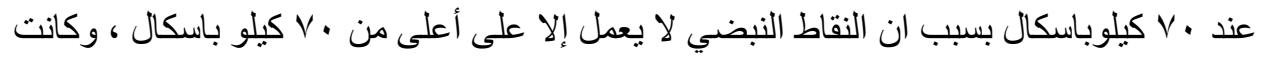

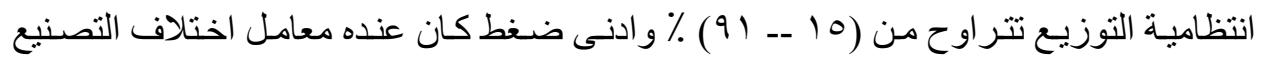

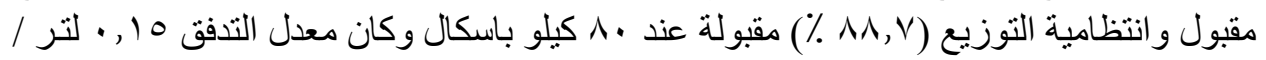
ساعة. الاختلاف في معامـل التصـنيع: كـان معامـل اختلاف التصـنيع للمعـاملات التثلاث كالتـالي: في المعاملة الاولى نراوح من (0.36 -0.132) و الثانية تر اوح من (0.22 (0.07 -0.07) و الثالثة تر اوح من (0.95-0.07).

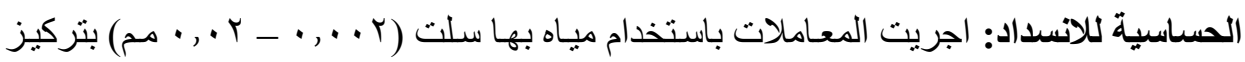

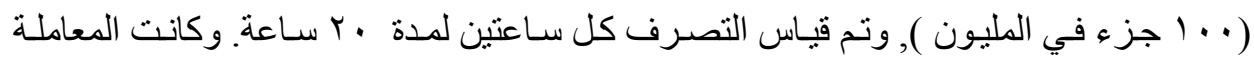

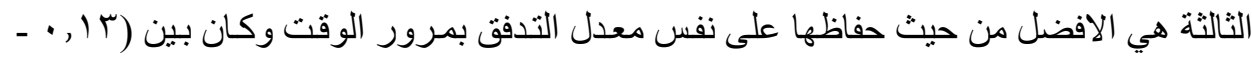

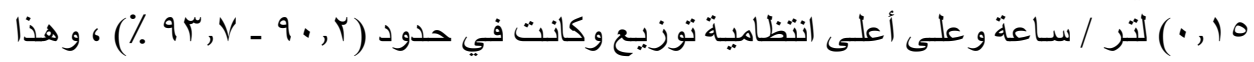

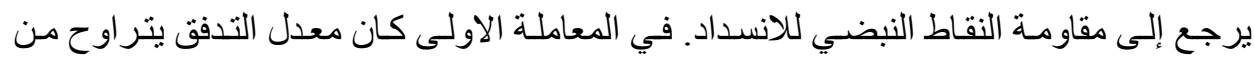

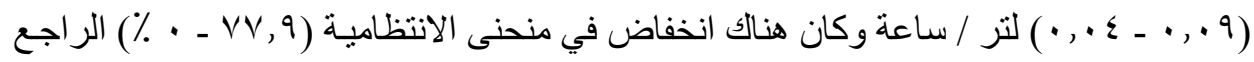

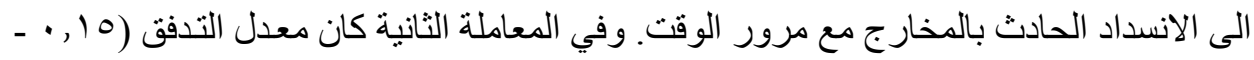

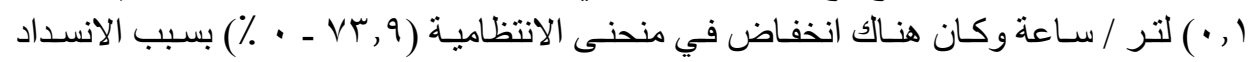

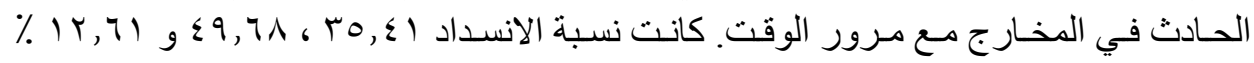

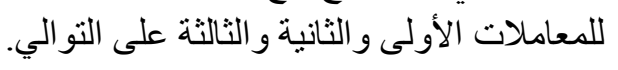

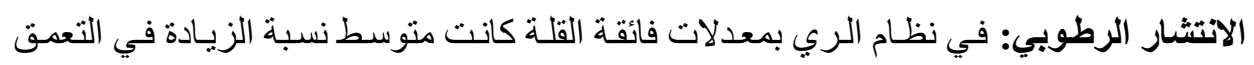

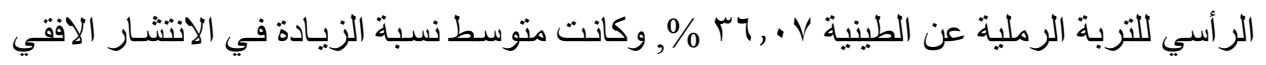

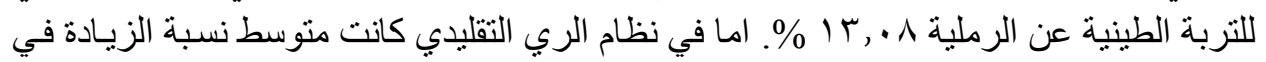

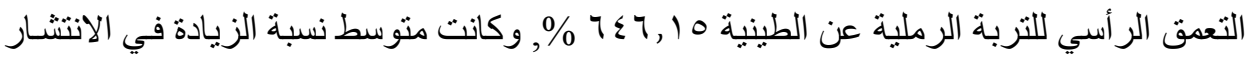

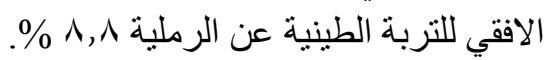
التكـاليف: تم حسـاب تكاليف الانتـاء لخمس افدنة تحت نظـام الري بـالتنقيط التقليدي و الري بالمعدلات فائقة القلة تحت نفس ظروف التشغيل وكانت النتائج كالتالي:

اجمالي التكاليف للري التقليدي 23872.7 L.E وللري بالمعدلات فائقة القلة .

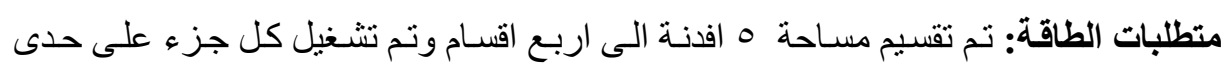

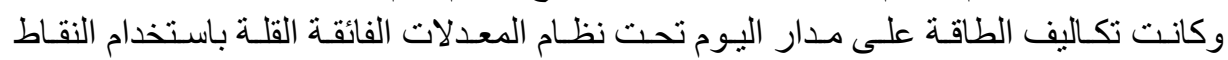

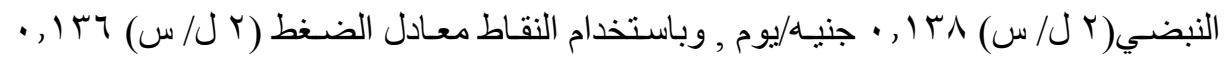

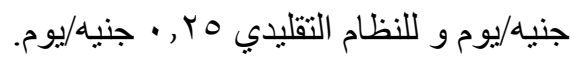
التوصيات: مـن النتائج السـابقة يلاحظ ان المعاملـة الثالثة افضـل معاملة مـن حيث الانتظاميـة

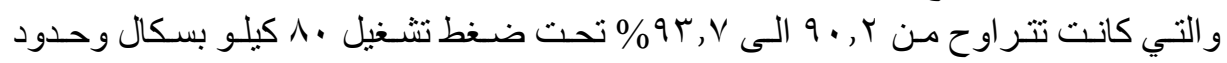
تصرف من سا , • الى 0 ا , • لتر/ساعة وكان النقاط النبضي مقاوم للانسداد. 